Federal Reserve Bank of Minneapolis

Research Department Staff Report 453

November 2010

\title{
Why Have Economic Reforms in Mexico Not Generated Growth?*
}

\author{
Timothy J. Kehoe \\ University of Minnesota, \\ Federal Reserve Bank of Minneapolis, \\ and National Bureau of Economic Research
}

Kim J. Ruhl

Stern School of Business, New York University

\begin{abstract}
Following its opening to trade and foreign investment in the mid-1980s, Mexico's economic growth has been modest at best, particularly in comparison with that of China. Comparing these countries and reviewing the literature, we conclude that the relation between openness and growth is not a simple one. Using standard trade theory, we find that Mexico has gained from trade, and by some measures, more so than China. We sketch out a theory in which developing countries can grow faster than the United States by reforming. As a country becomes richer, this sort of catch-up becomes more difficult. Absent continuing reforms, Chinese growth is likely to slow down sharply, perhaps leaving China at a level less than Mexico’s real GDP per workingage person.
\end{abstract}

\footnotetext{
* This work was undertaken with the support of the National Science Foundation under grant SES-09-62865. The paper was prepared for a mini-symposium in the Journal of Economic Literature on lack of economic growth in Mexico following its economic reforms. The editor, Janet Currie, provided several very helpful suggestions. José Asturias and Sewon Hur provided extraordinary research assistance. We thank Tom Holmes, Ellen McGrattan, Ed Prescott, and Jaime Serra-Puche for helpful discussions. The data used in this paper are available at www.econ.umn.edu/ tkehoe and at www.kimjruhl.com. The views expressed herein are those of the authors and not necessarily those of the Federal Reserve Bank of Minneapolis or the Federal Reserve System.
} 


\section{Introduction}

During the decade that followed its severe economic crisis of 1982-85, the Mexican government implemented a series of market-oriented reforms that culminated in the implementation of the North American Free Trade Agreement (NAFTA) in 1994. These reforms included fiscal reforms, privatization of government operated firms, and opening the economy to trade and foreign investment. In spite of these reforms, Mexico’s economic growth since 1985 has been modest, at best. This growth is especially disappointing if we compare it with that of China, another large, less developed country that started opening itself to the rest of the world after Mexico.

In this paper, we ask why Mexico’s reforms did not result in higher rates of economic growth. We focus on the reforms that opened Mexico to trade and foreign investment. It is worth noting that one of the authors was a proponent of these reforms as a means for achieving higher growth in Mexico (see Timothy J. Kehoe 1992, 1994). Figure 1 presents data on Mexico’s trade in goods and services as a percentage of its GDP, while figure 2 presents data on inflows of foreign direct investment (FDI). Notice that Mexico’s apertura, or opening, resulted in large increases in trade and FDI. (See Kehoe 1995 for the details of the reforms involved in the apertura.) In particular, Mexico's trade and inward FDI as shares of its GDP reached levels comparable to those achieved by China. Figure 3 presents the disappointing data on economic growth in Mexico. While real GDP per working-age person (15-64 years old) grew by 510 percent (8.2 percent per year) in China over the period 1985-2008, it grew by only 10 percent (0.4 percent per year) in Mexico. ${ }^{1}$ Notice that the vertical axis in figure 3 has a log base 2 scale, so that China's relatively constant growth shows up as being close to linear.

[Figures 1, 2, and 3 here]

China and Mexico are major exporters and importers in the world economy. In 1995, China had the largest merchandise trade among countries classified by the International Monetary Fund as emerging and developing, accounting for 12.7 percent of emerging and developing trade, while Mexico was second, accounting for 7.0 percent. In 2008, China is still the largest trader at

\footnotetext{
${ }^{1}$ We use real GDP per working-age person, rather than real GDP per capita, because it measures better an economy's ability to produce goods and services, especially in the context of the neoclassical growth model that we discuss in section 4. When we discuss welfare in section 3, we use real GDP per capita. Another measure appropriate for welfare would be real GDP per adult equivalent. All of the data used in this paper are available at www.econ.umn.edu/ tkehoe and at www.kimjruhl.com.
} 
22.3 percent, while Mexico has dropped to third, at 5.4 percent, slightly behind Russia. China and Mexico had some of the largest receipts of FDI among emerging and developing economies. In 1995, China was the largest recipient of FDI to emerging and developing economies, accounting for 33.4 percent, while Mexico was second, accounting for 8.5 percent. By 2008, China has remained the largest recipient of FDI to emerging and developing economies, at 14.8 percent, but Mexico has fallen to seventh, at 3.2 percent, falling behind Russia, Hungary, Brazil, India, and Saudi Arabia. ${ }^{2}$

We begin by reviewing the existing literature, asking whether it provides a convincing answer to the question of why Mexico stagnated after opening itself to trade while China grew rapidly. Although a number of studies are informative, we do not find an answer to this question. As Claustre Bajona, Mark J. Gibson, Kehoe, and Kim J. Ruhl (2010) argue, standard trade models do not imply that opening to trade increases productivity or real GDP, but that it increases welfare. Examining the mechanisms through which opening to trade increases welfare, we find evidence that welfare increased more in Mexico than the real GDP data indicate and that the growth gap between Mexico and China is not as large. Nonetheless, a large growth gap remains, and, to account for this growth gap, we need to identify a critical factor that impeded growth in Mexico but not in China, or a different factor that spurred growth in China but not in Mexico. Performing a simple growth accounting exercise, we find that this sort of factor, when inserted into a growth model, would need to explain why total factor productivity (TFP) stagnated in Mexico while it grew rapidly in China. We review a number of possible factors suggested by the literature - some associated with trade and foreign investment policies and others associated with domestic policies.

We conclude by suggesting directions for future research. In particular, we sketch out a theory suggested by the research of Stephen L. Parente and Edward C. Prescott $(1994,2002)$ and Kehoe and Prescott $(2002,2007)$. In this theory, technology in the form of the stock of useable knowledge in the industrial leader — which we identify as being the United States over the past century - grows at a constant rate. If institutions and economic policies are constant, this implies a constant rate of growth of real GDP per working-age person. Developing economies like Mexico and China can grow faster than this rate by improving institutions and reforming policies. The possibilities for such catch-up growth depend on the distance of the developing

\footnotetext{
${ }^{2}$ FDI inflows are more volatile than merchandise trade, so the list of leaders changes more frequently.
} 
economy from the frontier, the level of real GDP per working-age person in the United States. In Mexico - which, in spite of its slower growth, is still closer to the United States in terms of real GDP per working-age person than is China - this catch-up growth is more difficult. Our theory suggests that the factors that currently impede growth in Mexico, such as inefficient financial institutions, and insufficient rule of law, and rigidities in the labor market, do not yet do so in China because China has not yet reached a sufficient level of economic development. We hypothesize that, as China grows, these factors will become more important and, absent significant reforms, growth in China will slow down sharply, as it has in Mexico.

\section{Literature review}

We now survey the existing literature related to our question of why Mexico stagnated after opening itself to trade and foreign investment while China grew rapidly. Since this literature is large, we focus on those studies particularly relevant to the theory that we sketch out in section 5.

\subsection{Cross-country growth regressions}

In contrast with the approach of this paper, which compares the experience of Mexico after it opened itself to foreign trade and investment with that of China, there is a large literature that includes measures of openness in cross-country growth regressions. The literature on the empirical relationship between trade policy regimes and economic performance goes back to the 1970s. Sebastian Edwards (1989) provides a comprehensive summary of the early work. It is worth noting that Edwards criticizes much of the previous literature, and in particular the World Bank (1987), for employing univariate measures of policies that divide countries into open or closed, noting that such divisions are often highly subjective and run the risk of simply verifying the policy preferences of the researchers doing the study.

We focus on the seminal work of Jeffrey Sachs and Andrew Warner (1995), who construct a univariate measure of openness that classifies a country as closed if it had any one of five characteristics: (1) a high average tariff rate, (2) nontariff barriers on a large fraction of imports, (3) a socialist economic system, (4) a state monopoly over major exports, or (5) a high blackmarket premium during either the 1970s or the 1980s. Sachs and Warner find that countries that are open, in that they have none of these characteristics, have on average 2.4 percent per year higher growth in real GDP per capita than those that were closed. Of particular relevance to the 
comparison between Mexico and China is Sachs and Warner's classification of Mexico as closed up until 1986 but open thereafter and their classification of China as being closed. They classify China as a socialist economy and note that, although China has progressively liberalized since 1978, its trading system was still rife with quantitative restrictions at least as of 1994. Updating the Sachs-Warner classification, Romain Wacziarg and Karen Horn Welch (2008) classify Mexico as open but China as still closed because of its socialist regime and its black market premium.

Francisco Rodríguez and Dani Rodrik (2000) criticize Sachs and Warner, pointing out that the power of the openness variable in their regressions derives mostly from the state-monopolyof-exports and the black-market-premium criteria. These criteria, Rodríguez and Rodrik argue, are not measures of trade policy per se and, overall, the Sachs-Warner openness variable serves as a proxy for a very broad range of institutional and policy variables. Warner (2003) responds to this criticism by showing that the average tariff on imports of capital and intermediate goods has a significantly negative effect on growth and that the state-monopoly-of-exports and the black-market-premium criteria can be dropped as long as he controls for initial GDP per capita. It should be noted that, in Warner's data set, Mexico has lower than average tariffs on capital and intermediate goods and China has higher than average tariffs. As Rodríguez (2007) points out, the message of Warner (2003) is much more nuanced than that of Sachs and Warner (1995) and, in particular, openness seems to have a more positive effect on poorer countries than on middle income countries.

Another attempt to respond to Rodríguez and Rodrik’s (2000) criticism of Sachs and Warner (1995) is that of David Dollar and Aart Kraay (2004), who examine the impact of first differences in openness to trade on growth. They identify "globalizers" as countries that significantly increased their ratios of trade to GDP between the late 1970s and the late 1990s. Dollar and Kraay find that globalizers experienced large increases in their growth of real GDP per capita, while non-globalizers saw their growth rates decline. According to the Dollar-Kraay criterion, both Mexico and China are globalizers.

Three general aspects of the literature are worth noting:

First, there is a positive and robust relationship between a country's trade as a share of GDP and its growth rate, as established in the work of such researchers as Jeffrey A. Frankel and David Romer (1999), Francisco Alcalá and Antonio Ciccone (2004), and Dollar and Kraay 
(2004). As a number of researchers, including Rodríguez and Rodrik (2000) and Rodríguez (2007), have pointed out, however, the trade share is not a direct measure of policy and the causal relation between the trade share and growth is problematical. Howard L. M. Nye, Sanjay Reddy, and Kevin Watkins (2002), for example, argue that Dollar and Kraay's attempt to relate their results involving changes in trade shares to changes in tariffs is highly sensitive to the years chosen for tariff changes and the years chosen for growth rates and that Dollar and Kraay's results are not robust.

Second and relatedly, the relationship between measures of policies related to openness and growth does not seem to be robust: A number of researchers - including Ann Harrison (1996) and Edwards (1998) in addition to those whose work we have already discussed — find a large and significantly positive relationship between policies related to openness and growth. Other researchers - like Ha Yan Lee, Luca A. Ricci, and Roberto Rigobon (2004) — find a positive, but small, relationship. Still others - including Rodrik, Arvind Subramanian, and Francesco Trebbi (2004) in addition to those whose work we have already discussed — do not find a significant relationship between policies related to openness and economic growth. Other researchers find more nuanced results: In addition to, and in contrast with, the work of Warner (2003), Steve Dowrick and Jane Golley (2004) and David N. DeJong and Marla Ripoll (2006) find that openness has a significantly positive impact on growth only for developed countries, while Halit Yanikkaya (2003) actually finds that openness has a negative effect on economic growth for less developed countries.

Third, many of the researchers who study the relationship between openness and growth do so without being closely guided by a theoretical model. Other researchers, particularly those working in the 1990s, are guided by the theoretical work on endogenous growth by researchers such as Luis A. Rivera-Batiz and Paul M. Romer (1991). In this sort of model, there are typically scale effects from positive externalities in production. That is, everything else being equal, larger countries should grow more rapidly. International trade can allow a small country to benefit from these positive externalities. This sort of theory indicates that well-specified growth regressions need to control for an appropriate measure of country size when studying the impact of openness. Typically, in these theories, a smaller country benefits more from opening to international trade than does a larger country. Once again, the empirical results are mixed: Frankel and Romer (1999) and Alcalá and Ciccone (2004) find a positive relationship between 
population size and economic growth. Alberto Alesina, Enrico Spolaore, and Wacziarg (2000) and Spolaore and Wacziarg (2005) find the same relationship and also find a negative (although statistically insignificant) coefficient for the interaction term of population size with their measure of openess. On the other hand, Chris Milner and Tony Westaway (1993), Harrison (1996), and Xavier Sala-i-Martin (1997) find no significant link between measures of population size and growth. David A. Backus, Patrick J. Kehoe, and Kehoe (1992) similarly find that growth and size of GDP are largely uncorrelated, but they do find evidence of significant scale effects in manufacturing, and evidence that these effects are larger and more significant when they control for a measure of openness suggested by the theory of Rivera-Batiz and Romer (1991).

\subsection{Studies of Mexico's stagnation}

We are by no means the first researchers to study why Mexico has stagnated in spite of its reforms. In this section we review the research that identifies factors believed to impede growth in Mexico. For each of these factors we ask: Does China share this characteristic? And, if so, why has it not impeded growth in China? In many cases we find that the factors associated with slow growth in Mexico are also present in China, so we are left to ask: Why do these factors impact growth differently in the two countries?

The most popular set of theories for Mexico's stagnation focuses on its inefficient financial system and lack of contract enforcement. Raphael Bergoeing, Raimundo Soto, Kehoe, and Kehoe (2002, 2007), for example, compare the growth experiences of Mexico and Chile following their economic crises in the early 1980s. While Mexico stagnated, Chile grew rapidly. After examining fiscal reforms, privatization, and reforms of policies related to trade and foreign investment policy in Mexico and Chile, these researchers conclude that the crucial difference between policies in Mexico and Chile are those related to the financial system and to bankruptcy proceedings. They sketch out a model of firms with heterogeneous productivity and argue that an inefficient financial system can misallocate labor and capital, leading to a low measure of TFP. Furthermore, inefficient bankruptcy proceedings can keep inefficient firms alive and impede the entry of new, more efficient firms, slowing down the growth of TFP.

Anne Krueger and Aaron Tornell (1999) and Tornell, Frank Westermann, and Lorenza Martinez (2003) study the recovery of the Mexican economy following the financial crisis of 
1994-1995. They find that, while the traded goods sector grew rapidly, the nontraded sector recovered sluggishly. They argue that this occurred because domestic bank lending dried up after the crisis, and traded goods firms were able to obtain financing from abroad while nontraded goods firms were not. One of the reasons that lending dried up was that poor contract enforcement — such as the inefficient bankruptcy procedures identified by Bergoeing et al. (2002, 2007) — generated a large quantity of nonperforming loans. Tornell, Westermann, and Martinez (2003) develop a model in which rapid GDP growth cannot be sustained over a long period if it is driven only by growth in the traded goods sector, because firms producing traded goods need nontraded inputs.

The problem with identifying a poorly functioning financial system and lack of contract enforcement as the factors that differentiate Mexico from China is that China also has a poorly functioning financial system and lack of contract enforcement. Thomas G. Rawski (1994) and Franklin Allen, Jun Qian, and Meijun Qian (2005) establish that China has been able to achieve phenomenal economic growth with a poorly functioning financial system and legal system and without any significant reforms to these systems. Studying the Chinese experience, Alessandra Guariglia and Sandra Poncet (2008) go so far as to question whether an efficient financial system is necessary for growth at all.

Other researchers identify other possible impediments to growth in Mexico. Gueorgui Kambourov (2009), for example, argues that a rigid labor market kept Mexico from benefiting as much from opening to trade as Chile did. Nora Lustig (2001) identifies an institutional vacuum in the agricultural sector after government intervention there was reduced as leaving many producers with less access to credit and technical assistance. Juan Carlos Moreno-Brid, Jesus Santamaria, and Juan Carlos Rivas Valdivia (2005) identify a sharp fall in public investment. It is worth noting that Lustig and Moreno-Brid et al. also identify problems in the financial system as being significant barriers to growth in Mexico.

The conclusion that we draw from these studies is that factors like an inefficient financial sector, lack of contract enforcement, and rigidities in the labor market kept Mexico from benefiting from its reforms to policies involving foreign trade and investment. China also has these same problems, but we will argue that these did not impede growth as they did in Mexico because China is at a lower level of development. Perhaps China's growth is even part of Mexico’s problem. M. Ayhan Kose, Guy Meredith, and Christopher Towe (2005), for example, 
identify increased competition from China in its export markets, as well as problems in the legal system and rigidities in the labor and telecommunications markets, as barriers to growth in Mexico.

\subsection{Studies of China's fast growth}

A number of researchers have identified rapid TFP growth as the driving force behind Chinese economic growth. Loren Brandt and Xiaodong Zhu (2009) find that about half of Chinese TFP growth was due to productivity differences between entering and exiting firms during 19982005. Chang-Tai Hsieh and Peter J. Klenow (2009) identify reallocation of resources from inefficient firms to efficient firms as a significant determinant of this TFP growth. We ask: Why have these factors not been at work in Mexico?

Policies related to foreign trade and investment played significant roles in the reallocation of resources that led to TFP growth. Bajona and Tianshu Chu (2010) argue that China's 2001 accession protocol to the World Trade Organization forced the Chinese government (or gave reformers inside the government the political clout) to drastically cut subsidies to the stateowned sector and show that this generated a reallocation from inefficient state-owned firms to efficient private firms. Zuliu F. Hu and Mohsin S. Khan (1997) argue that reforms that led to FDI attracted efficient foreign firms to invest in China. Zheng Song, Kjetil Storesletten, and Fabrizio Zilibotti (forthcoming) build a model to account for China's recent growth experience, which is characterized by substantial reallocation within the manufacturing sector in an economy with large financial imperfections.

It would be tempting to hypothesize that the mechanisms that generated TFP growth in manufacturing in China were not present in Mexico, but this does not seem to be the case. In particular, using firm level data for Mexico, Ernesto López-Córdova (2003) finds that trade and

foreign investment reforms resulted in large increases in productivity in the manufacturing sector in Mexico, especially in the machinery and equipment, computing equipment, and precision instruments industries. This suggests that problem in Mexico is lack of productivity growth, not in manufacturing, but in the rest of the economy. It further suggests that we should look at lack of competition in other sectors in Mexico — such as petroleum extraction, electricity, telecommunications, and transportation — for the factors inhibiting productivity growth. 
We could also hypothesize that China has been able to grow because it has a strong central government that has been able to overcome some of the problems associated with poorly functioning markets, while Mexico has not been able to do this. This hypothesis is worth exploring, but it is worth pointing out two reasons for doubting it: First, Mexico became a democracy only in the mid-1990s; previously it had a one-party system that was in many ways as strong and centralized as that in China. Furthermore, the Mexican government controlled the banking system from 1982 through 1991, and Bergoeing et al. (2002, 2007) identify the inefficient allocation of credit during this period as a major factor in Mexico's poor economic performance. Second, Bajona and Chu (2010) argue that until China joined the WTO, the banking system there served mostly to funnel savings into investment in inefficient state-owned enterprises. Allocation of credit by the government seems to have been the major problem in the financial systems in both Mexico and in China, not a remedy for other problems.

\section{Gains from trade and real GDP}

The empirical evidence on the link between trade and growth is inconclusive. What do theoretical models of international trade predict should happen when a country liberalizes trade? Perhaps surprisingly, the workhorse models of trade — such as the Ricardian models of Rudiger Dornbusch, Stanley Fischer, and Paul A. Samuelson (1977) and Jonathan Eaton and Samuel S. Kortum (2002), or the imperfect competition models of Paul Krugman (1980) and Marc J. Melitz (2003) — do not yield a clear relationship between trade and real GDP. In these models, real GDP can increase, can remain unchanged, and can even decrease after tariffs are reduced!

This result follows from the way in which changes in the terms of trade are incorporated into real GDP. Bajona et al. (2010) show that the change in real GDP from a change in tariffs can be decomposed into two parts: the change in real GDP at factor prices and the change in real tariff revenues,

$$
\Delta G D P\left(\tau_{t}, p_{t}\left(\tau_{t}\right)\right)=\Delta G D P^{F}\left(\tau_{t}, p_{t}\left(\tau_{t}\right)\right)+\Delta T\left(\tau_{t}, p_{t}\left(\tau_{t}\right)\right)
$$

where $p_{t}$ is the terms of trade, and $\tau$ is an ad valorem tariff. If decreasing tariffs changes the country's terms of trade, real GDP at factor prices will weakly decrease. The lower tariffs also generate an increase in imports, and the tariff revenue associated with those imports, computed at the base period (higher) tariff rate, increases. The change in real GDP is the net effect. If real tariff revenues increase enough to offset the decline in real GDP at factor prices, real GDP 
increases; if the change in tariff revenues is small, real GDP decreases. The effect of the terms of trade on real GDP in a country without tariffs is addressed in Ulrich Kohli (2004), and in models with tariffs, in Kehoe and Ruhl (2008) and Robert C. Feenstra, Benjamin R. Mandel, Marshall B. Reinsdorf, and Matthew J. Slaughter (2009).

The ambiguous impact of trade liberalization on real GDP does not imply an ambiguous impact of liberalization on welfare: All of the models considered by Bajona et al. predict that trade reform increases welfare. Accurately measuring the gains from trade for Mexico and China is an inherently model specific exercise. Costas Arkolakis, Arnaud Costinot, and Andrés Rodríguez-Clare (2010), for example, show that, for a class of models, the change in real income in a country is a function of the import penetration ratio and a parameter related to the elasticity of substitution between imports and domestic goods. Changes in import penetration ratios are similar in Mexico over 1990-2000 and China over 1998-2008, suggesting that, as fractions of real GDP terms, the gains from trade in China and Mexico are similar, although in absolute terms, Mexico's gains are much larger than China's. Rather than go into model specific details here, we consider two other measures: an adjustment to real GDP to account for terms of trade effects and a measure that accounts for the gains from the greater varieties available through trade. These measures indicate that Mexico has gained more from trade than has China.

It is worth noting that this comparison assumes, for the moment, that China's higher GDP growth was not itself a gain from trade. We could restate our comparison as saying the gains from trade identified by standard models have been higher in Mexico than in China.

\subsection{Gains from the terms of trade}

Trade liberalization — and, more broadly, globalization — brings about changes in the terms of trade. Changes in the terms of trade impact welfare in the country but will generally not translate into changes in real GDP, as discussed above. Kohli (2004) argues that the invariance of real GDP to changes in the terms of trade makes real GDP a poor measure of country progress; Kehoe and Ruhl (2008) and Feenstra et al. (2009) study the impact (or lack thereof) of the terms

of trade on measures of productivity. These authors suggest several alternatives to real GDP; here we use the real gross domestic income (GDI) of a country, as defined by the United Nations' System of National Accounts, to capture the impact of changes in the terms of trade on welfare and productivity. 
Real GDI treats the domestic components of expenditure in the same way that real GDP does - the components are deflated by their respective price indices — but it differs in the deflation of the trade balance. To compute real GDI, we deflate the trade balance by the import price deflator: Exports are valued in terms of the amount of imports they could purchase,

$$
G D I_{t}=\frac{C_{t}}{P_{t}^{C}}+\frac{I_{t}}{P_{t}^{I}}+\frac{G_{t}}{P_{t}^{G}}+\frac{X_{t}-M_{t}}{P_{t}^{M}} .
$$

In figure 4 we plot the percentage deviation of real GDI from real GDP for Mexico and China. We refer to this measure as the terms of trade premium: the gain, relative to real GDP, that accrues to a country because of changes in the terms of trade. In Mexico, the average terms of trade premium is 0.17 percent per year, but the crisis in 1994-1995 was accompanied by a sharp deterioration in the terms of trade; the impact of the financial crisis was worse than real GDP indicated, and the recovery more robust. In China, the terms of trade have steadily deteriorated and the resulting adjustment to GDP is striking: Chinese real GDP overstates the growth in real gross domestic income by almost 8 percentage points over the decade considered. The intuition for this results is simple: The policies that keep the relative price of imports in China high make Chinese consumers worse off than the real GDP data indicate.

[Figure 4 here]

\subsection{Gains from new varieties}

The "new trade models" based on differentiated varieties and increasing returns to scale (for example, Krugman 1980 and Melitz 2003) imply that trade liberalization not only changes the prices of goods that were already available for consumption, but also changes the composition of varieties that are available for consumption. Kehoe and Ruhl (2003) show that, following trade liberalization, newly traded goods can significantly change the composition of trade between countries. Capturing the impact of changing varieties is difficult with standard measurements because it is difficult to account for a good when its initial price is not observed. The seminal contribution in Feenstra (1994) is a result that, for constant elasticity of substitution (CES) preferences, the impact of new varieties on prices can be measured despite the absence of initial prices for some goods.

We apply the technique developed in Feenstra (1994) to compute the gains from the importation of new varieties for China and Mexico. In what follows, we construct a measure of 
the bias in import prices that exists when the changing composition of varieties is ignored in price indices. This bias allows us to compute the gains from the greater varieties that can be consumed with trade in China and Mexico. Our approach follows Christian Broda and David E. Weinstein (2006), which measures the gains from new varieties in the United States.

We classify imports into goods, which are collections of varieties. Goods and varieties enter utility through a nested CES utility function. The set of all imported goods is $G$, and for each $g \in G$, the set of all varieties available at time $t$ is $I_{g t}$. Note that we have assumed the set of goods is constant over time, while the set of varieties can change. The sub-utility of imported good $g$ at time $t$ is an aggregation of varieties,

$$
M_{g t}=\left(\sum_{i \in I_{g t}} d_{g i t} X_{g i t}^{\frac{\sigma_{g-1}}{\sigma_{g}}}\right)^{\frac{\sigma_{g}}{\sigma_{g}-1}},
$$

where $x_{g i t}$ is the consumption of variety $i$ of good $g$ and $d_{g i t}$ is a variety specific demand shifter. All of the varieties of a good have the same elasticity of substitution, $\sigma_{g}>1$, but this elasticity may differ by good. Goods are aggregated into a composite import good in a second CES aggregator, and, finally, the composite import good and a composite domestic good are combined in the utility function.

We would like to price the composite import good. Feenstra (1994) shows that, given the vectors of prices and quantities, $\mathbf{p}_{g t}$ and $\mathbf{x}_{g t}$, the exact price index is

$$
\pi^{M}\left(\mathbf{p}_{g t}, \mathbf{p}_{g t-1}, \mathbf{x}_{g t}, \mathbf{x}_{g t-1}, I_{g}\right)=\prod_{g \in G} P_{g}^{M}\left(\mathbf{p}_{g t}, \mathbf{p}_{g t-1}, \mathbf{x}_{g t}, \mathbf{x}_{g t-1}, I_{g}\right)^{\omega_{g t}} \times \prod_{g \in G}\left(\frac{\lambda_{g t}}{\lambda_{g t-1}}\right)^{\frac{\omega_{g t}}{\sigma_{g}-1}} .
$$

The index $P_{g}^{M}$ is the CES ideal price index, for good $g$, computed over the varieties present in both periods, $I_{g}=I_{g t} \cap I_{g t-1}$, as derived in Kazuo Sato (1976) and Yrjö O. Vartia (1976). $\omega_{g t}$ is the ideal log change weight, and $\lambda_{g t}$ is the share of the common varieties in total expenditure on good $g$,

$$
\lambda_{g t}=\frac{\sum_{i \in I_{g}} p_{g i t} x_{g i t}}{\sum_{c \in I_{g t}} p_{g i t} x_{g i t}}
$$


This is an important result: it allows us to compute the change in the price index even though we do not have prices for all varieties in all periods. Further details are available in Feenstra (1994) and Broda and Weinstein (2006).

The second product on the right hand side of equation (4) is the contribution of new varieties to the price index - what Broda and Weinstein name the aggregate import bias. The lambda ratio, $\lambda_{g t} / \lambda_{g t-1}$, measures the extent to which the changing varieties impact expenditure on the common set of goods. If the new varieties have small expenditure shares, the lambda ratio is close to one, and the bias is small. The lambda ratio is weighted by a term that involves both the good's elasticity of substitution and the good's weight in total import expenditure. Goods with fewer substitutable varieties, or goods with larger weights, have larger impacts on the bias.

To compute the aggregate import bias, we define a good to be a three-digit category of the Harmonized System (HS). We define a variety to be a six-digit HS code - country pair. A good, for example, would be 090, "Coffee, tea, mate, and seed spices," while a variety would be 090111-Colombia, "Coffee, not roasted, not decaffeinated” from Colombia, which is a different variety than 090111-Costa Rica. We have 164 goods. In China, the median number of varieties per good was 300.5 in 1998 and grew to 406.0 in 2008. In Mexico, the median number of varieties per good rose from 150.5 in 1990 to 230.5 in 2000.

We use the country-specific elasticities estimated in Broda, Joshua Greenfield, and Weinstein (2006) in our calculations for China and Mexico. The mean and median elasticities are reported in table 1. Table 1 also summarizes the lambda ratios in the two countries. The distributions of the lambda ratios are similar; the median lambda ratios are near 0.95 and the 95th percentile ratio is about 1.03. The bias in the aggregate import price index, over the 11-year period, is 0.94 for Mexico: the price of a unit of the composite import in Mexico has fallen by 6 percent over the period because of the increase in imported varieties. The composite import price in China fell by about 5 percent.

\section{[Table 1 here]}

We can put these numbers into perspective by calculating the amount of extra income a consumer would need in order to achieve the same increase in utility over the period without the new varieties. This equivalent variation is computed as the inverse of the aggregate import price bias, weighted by the share of imports in total expenditure. We report the import weights 
and the equivalent variation in table 1. The consumer in Mexico needs an extra 1.42 percent of his or her 1990 income — and in China, 1.01 percent of his or her 1998 income — to be indifferent to the new varieties of imports accumulated over the next ten years.

In table 2 we summarize the impact of trade on real income growth. Column 2 reports the annual growth rate of the terms of trade premium that we calculated in the previous section. For China, this implies that real GDP overstates the growth in real income by 0.76 percent per year due to the deterioration of the terms of trade. Accounting for both the gain in varieties and the adjustment for the terms of trade, the growth rate of real income per capita in China is 8.33 percent, compared with the 8.99 percent growth in real GDP. In Mexico, the gains from trade imply that real income has grown about 0.30 percent per year faster than real GDP. As reported in the World Bank, in Mexico, real GDP per capita at purchasing power parity (PPP) is 10,121 2005 U.S. dollars in 1990 and 2,325 dollars for China in 1998. The absolute gain from these two adjustments is 319 dollars per capita for Mexico in 2000, and a loss of 148 dollars per capita for China in 2008.

\section{[Table 2 here.]}

Our measurements suggest that Mexico, despite slow growth in GDP, has reaped substantial benefits from liberalization. We should be clear, however, that our measurements are only capturing the improvement in welfare that comes from consuming less expensive goods - or from consuming new varieties of goods - as a result of lower trade barriers. The gains from trade measured here do not account for other channels through which trade can impact welfare, such as technology that may be embodied in imported capital goods or spillovers from the operations of multinational firms. We discuss these possibilities below.

\section{Neoclassical growth model and power of productivity}

We now argue that a successful theory of why Mexico stagnated even as it opened itself to trade and foreign investment while China grew rapidly needs to focus on why productivity stagnated in Mexico while it grew rapidly in China. To do so, we employ the growth accounting developed by Kehoe and Prescott (2002, 2007). Kehoe and Prescott use the neoclassical growth model to guide their view of economic data. The model features an aggregate Cobb-Douglas production function,

$$
Y_{t}=A_{t} K_{t}^{\alpha} L_{t}^{1-\alpha}
$$


where $Y_{t}$ is output, $A_{t}$ is TFP, $K_{t}$ is capital, and $L_{t}$ is labor input. If the working-age population grows at a constant rate, $N_{t}=N_{0} \eta^{t}$, and TFP grows at a constant rate, $A_{t}=A_{0} \gamma^{(1-\alpha) t}$, then the economy has a balanced growth path in which all quantities per working-age person grow at the rate $\gamma-1$ except for hours worked per working-age person, which is constant. In our growth accounting for Mexico and China, we assume that hours worked per worker is constant, which allows us to use the number of workers as a measure to the labor input. We do this because we do not have data on hours worked for China. Although we have such data for Mexico, we do not use them to be consistent. (The results change very little, however, if we use Mexican hours data.)

Kehoe and Prescott (2002, 2007) rewrite the production function (6) as

$$
Y_{t} / N_{t}=A_{t}^{1 /(1-\alpha)}\left(K_{t} / Y_{t}\right)^{\alpha /(1-\alpha)}\left(L_{t} / N_{t}\right) .
$$

They note that, along a balanced growth path, when $A_{t}$ grows at a constant rate, the capitaloutput ratio $K_{t} / Y_{t}$ and the participation rate $L_{t} / N_{t}$ are constant. Kehoe and Prescott show that U.S. data over the period 1960-2000 are close to a balanced growth path. Here we show that Chinese data over the period 1985-2008 are close to a balanced growth path, albeit at a very high rate of growth. Figure 5 decomposes the growth in output, $Y_{t} / N_{t}$, measured as real GDP per working-age person in China into a productivity factor, $A_{t}^{1 /(1-\alpha)}$, a capital factor, $\left(K_{t} / Y_{t}\right)^{\alpha /(1-\alpha)}$, and a labor factor $L_{t} / N_{t}$. Once again the scale on the vertical axis is log base 2. Notice that the Chinese growth is close to balanced in that the growth in $Y_{t} / N_{t}$ is close to that in $A_{t}^{1 /(1-\alpha)}$, and $\left(K_{t} / Y_{t}\right)^{\alpha /(1-\alpha)}$ and $L_{t} / N_{t}$ are close to constant. To be sure, there are deviations from balanced growth behavior. In the mid-1990s, growth in output $Y_{t} / N_{t}$ accelerates, and much of this acceleration is due to growth in the capital factor $\left(K_{t} / Y_{t}\right)^{\alpha /(1-\alpha)}$ and, especially, the labor factor $L_{t} / N_{t}$

\section{[Figures 5 and 6 here]}

Figure 6 presents the growth accounting for Mexico. The poor performance in terms of real GDP growth is driven by an even worse performance in terms of TFP growth. Since 1995, however, there has been some GDP growth, and that growth has been driven by TFP growth. 
Between 1995 and 2000, real GDP per working-age person grew by 3.2 percent per year, while overall, between 1995 and 2008, it grew by 1.7 percent per year.

In our growth accounting, growth in human capital shows up as growth in TFP. Fluctuations in factor utilization also show up as fluctuations in TFP, although this is probably more important in studying business cycle moments, like the 1994-1995 financial crisis in Mexico, than it is in studying growth over a decade or longer. The Kehoe-Prescott growth accounting in equation (7), in contrast to that of Robert M. Solow (1957) and Edward F. Denison (1962), takes into account the feature of the neoclassical growth model that, in a balanced growth path, as technological growth occurs, consumers will save so as to keep the capital-output ratio constant. Researchers like José De Gregorio and Jong-Wha Lee (2004) and Barry Bosworth and Susan M. Collins (2008), who use a growth accounting that looks at increases in output per worker as a function of variables that include capital per worker, typically find increases in TFP and increases in capital roughly equally important in accounting for growth. Our growth accounting - which imputes to the productivity factor the increase in capital necessary to keep the capital-output ratio constant and imputes to the capital factor only the increases in the capitaloutput ratio, that is, capital deepening - finds that capital is much less important and that increases in productivity are typically the driving force of economic growth.

Understanding that it is the growth in TFP that is essential for accounting for why some countries grow faster than others allows us to reassess some of the research that employs growth regressions. Of the research that we have discussed, Backus et al. (1992), Edwards (1998), and Alcalá and Ciccone (2004) directly address the need to account for TFP growth, making some measure of productivity growth, not growth in real GDP per capita, the dependent variable in their regressions.

Many other authors, going back to the late 1950s, have realized that understanding TFP growth is essential for understanding economic growth. Of particular relevance for the theoretical framework that we sketch out in the next section are William W. Lewis (2004) and Parente and Prescott (2002). Lewis (2004) uses case studies of different countries to show that productivity in other sectors, besides just manufacturing, is essential for determining relative income levels across countries. He also uses anecdotal evidence to argue that it is government policies that discourage the adoption of the best available technologies from the rest of the world that keep countries relatively poor. Parente and Prescott (2002) develop a model in which it is 
government policies and institutions like monopolies that impede new technology adoption that keep productivity, and therefore income per capita, low.

\section{Directions for future research and a proposed theoretical framework}

It is very possible that there are other aspects of openness — besides those emphasized by standard trade models — that generate growth. Researchers like Natalia Ramondo and Andrés Rodríguez-Clare (2009) and Ellen R. McGrattan and Prescott (2009) have stressed the role of FDI in transferring technology from one country to another. Researchers like Thomas J. Holmes and James A. Schmitz, Jr. (2001), Schmitz (2005), Gibson (2007), and James A. Costantini and Melitz (2008) have stressed the role of international trade in giving firms the incentives to pay the costs of adopting new technology.

Given our question of why Mexico stagnates while China grows, we need to ask of all of these papers why the mechanisms that they study worked in China but not in Mexico. A potential answer is that most of Mexico's trade and FDI inflows are with the United States. It may be that the predominance of intrafirm trade between Mexico and the United States reduces the incentives toward competition and innovation that would arise from trade and foreign investment reforms. Furthermore, Mexican manufacturing seems to be complementary with U.S. manufacturing, while Chinese manufacturing is a substitute for both Mexican and U.S. manufacturing. The emergence of China may have reduced the incentives toward innovation in both the United States and Mexico. These are possibilities worth studying, but it may be, as the work of researchers like López-Córdova (2003) suggests, that it is not the manufacturing sector — or at least those subsectors most involved in trade — that is responsible for Mexico's stagnation, but other sectors.

We propose a theoretical framework for studying these sorts of hypotheses as well as for reconciling some of the contradictory evidence on openness and growth in the empirical literature. We follow Kehoe and Prescott (2007) in using the economic performance of the United States over the past century as the starting point for our theory. Figure 7 presents the data on real GDP per working-age person in the United States, 1900-2008. Notice how close these data are to a constant growth path with 2 percent growth per year. The average growth rate during this period was 1.99 percent per year. There are small business cycle fluctuations around the constant growth path, and there is the major deviation during the Great Depression of 1929- 
39 and the subsequent World War II buildup. The United States has been the industrial leader, the richest major country in the world, since the early twentieth century, when it took over this role from the United Kingdom. We follow Kehoe and Prescott in hypothesizing that the near constant growth in the United States since then is driven by a near constant growth rate in the stock of knowledge useful in production. It should be stressed that this stock of knowledge is not measured TFP. Measured TFP depends on the stock of knowledge but also depends on the efficiency with which factors of production are allocated across firms and sectors in the economy.

\section{[Figure 7 here]}

The data in figure 7 are fascinating and invite speculation and theorizing. It is difficult, for example, to reconcile them with the once popular endogenous growth theories of authors like Romer (1986). As we have mentioned, the United Kingdom was the industrial leader during the nineteenth century, and it is possible that the European Union or even China might assume that role later in the twenty-first century. It is also possible that the technological progress may be slowly accelerating: According to Angus Maddison (1995), the average growth in the United Kingdom of real GDP per capita 1820-1900 was 1.2 percent per year. While all of this is interesting, it is largely irrelevant to our question involving growth in Mexico and China, countries that are far behind the industrial leader.

[Figure 8 here]

We hypothesize that the stock of knowledge, which has increased very smoothly over the past century or more, can be adopted, perhaps at some cost by countries that are behind the industrial leader. This would give rise to trend growth of close to 2 percent per year, at least after capital and labor have had time to adjust. The absolute level that a specific country is at compared to the industrial leader depends on its institutions and economic policies. Changes in these institutions and economic policies can cause depressions or booms. Eventually, however, if institutions and policies stabilize, and after capital and labor have adjusted, the country returns to trend growth. Figure 8 presents data on real GDP per working-age person in Mexico, 19002008 (except for 1910-1920 during the Mexican Revolution). After a period of slow growth involving the Revolution and the Great Depression of the 1930s and its aftermath, Mexico began to grow rapidly during the early 1950s. Between 1953 and 1981, Mexican real GDP per working-age person grew by 3.8 percent per year. From 1981 through 1995, Mexico suffered the 
great depression analyzed by Bergoeing et al. (2002, 2007), contracting by 1.7 percent per year. From 1995 to 2008, Mexico returned to close to trend growth, growing by 1.7 percent per year. [Figure 9 here]

To compare China with Mexico in terms of absolute level of income, we use the PPP real GDP data published by the World Bank (2008). Figure 9 depicts the data. China has been growing more rapidly than Mexico but is still substantially poorer in 2008. Specifically, China's GDP per working-age person in 2008 is 7,986 2005 U.S. dollars, which is only 38.5 percent of Mexico’s 20,755 dollars, and its GDP per capita in 2008 of 5,712 dollars is only 42.5 percent of Mexico’s 13,434 dollars. In terms of our theoretical framework, Mexico is not experiencing the rapid catch-up growth that China is experiencing now because it already had this sort of catch-up during the period 1953-1981.

In the theory that we propose, it is easier to grow faster than the industrial leader when an economy is far behind. An economy like China — or Mexico in 1953-1981 — can grow rapidly even with an inefficient financial system, lack of rule of law, and rigidities in the labor market. As the country gets closer to the industrial leader, however, rapid growth stops and the country levels off at the trend growth rate of GDP per working-age person of 2 percent per year or a little less. This seems to have occurred in Western Europe in the early 1970s, in Japan in the early 1990s, and in Chile in the late 1990s, to mention a few cases. How far short of the industrial leader the country levels off depends on its institutions and economic policies. Chile, for example, after spectacular growth following its great depression in the early 1980s, has had a level of real GDP per working-age person and a growth rate similar to those in Mexico since about 1998. Unless China continues to reform, we can expect economic growth there to slow down sharply at some point. It is an open question whether or not this slowdown will occur when China is still behind Mexico in terms of real GDP per working-age person. ${ }^{3}$

Many open questions remain to be resolved for our theory to be useful in accounting for the economic development of countries like Mexico and China: How can we modify the sorts of growth regressions to capture the periods of rapid growth followed by slowdowns predicted by

\footnotetext{
${ }^{3}$ Our theory suggests that it may be more fruitful to compare Mexico to economies at a similar level of economic development. Brazil is a frequently cited example. It is a country that has about 70 percent of the real GDP per working-age person of Mexico in 2008 but that has experienced higher rates of growth than Mexico since 2000. Over the period 1995-2008, however, the growth rate of GDP per working age person in Brazil has been 1.1 percent per year, less than Mexico's 1.7 percent per year. It has yet to be seen that Brazil is performing significantly better than Mexico.
} 
the theory? Is openness to trade and foreign investment even necessary for rapid growth when a country is very far behind the industrial leader? India's recent experience suggests not. Specific questions about the experience of Mexico remain to be resolved as well: Why was the period of rapid growth, 1995-2000, following the enactment of NAFTA so short? Or, put another way, why was the recovery following the 1982-95 great depression so modest? It may be that Mexico's slower growth since 2000 is the product of the contraction of the U.S. manufacturing sector and of competition with China. Perhaps most importantly, what sorts of reforms does Mexico need to enact to resume rapid catch-up growth? We hypothesize that these are reforms that eliminate the barriers to growth of an inefficient financial system, lack of rule of law, and rigidities in the labor market. In terms of more specific reforms, promoting competition in nonmanufacturing sectors like petroleum extraction, electricity, telecommunications, and transportation could spur productivity growth. 


\section{References}

Alcalá, Francisco, and Antonio Ciccone. 2004. “Trade and Productivity.” Quarterly Journal of Economics, 119(2): 613-46.

Alesina, Alberto, Enrico Spolaore, and Romain Wacziarg. 2000. "Economic Integration and Political Disintegration.” American Economic Review, 90(5): 1276-96.

Allen, Franklin, Jun Qian, and Meijun Qian. 2005. "Law, Finance, and Economic Growth in China.” Journal of Financial Economics, 77(1): 57-116.

Arkolakis, Costas, Arnaud Costinot, and Andrés Rodríguez-Clare. 2010. "New Models, Same Old Gains?” NBER Working Paper 15628.

Backus, David K., Patrick J. Kehoe, and Timothy J. Kehoe. 1992. "In Search of Scale Effects in Trade and Growth.” Journal of Economic Theory, 58(2): 377-409.

Bajona, Claustre, and Tianshu Chu. 2010. "Reforming State Owned Enterprises in China: Effects of WTO Accession.” Review of Economic Dynamics, 13(4): 800-23.

Bajona, Claustre, Mark J. Gibson, Timothy J. Kehoe, and Kim J. Ruhl. 2010. “Trade Liberalization, Growth, and Productivity.” http://www.econ.umn.edu/ tkehoe/papers/ BajonaGibsonKehoeRuhl.pdf.

Bergoeing, Raphael, Patrick J. Kehoe, Timothy J. Kehoe, and Raimundo Soto. 2002. “A Decade Lost and Found: Mexico and Chile in the 1980s.” Review of Economic Dynamics, 5(1): 166-205.

Bergoeing, Raphael, Patrick J. Kehoe, Timothy J. Kehoe, and Raimundo Soto. 2007. “A Decade Lost and Found: Mexico and Chile in the 1980s.” In Great Depressions of the Twentieth Century, ed. Timothy J. Kehoe and Edward C. Prescott, 217-56. Minneapolis: Federal Reserve Bank of Minneapolis.

Bosworth, Barry, and Susan M. Collins. 2008. “Accounting for Growth: Comparing China and India.” Journal of Economic Perspectives, 22(1): 45-66.

Brandt, Loren, and Xiaodong Zhu. 2009. “Accounting for China’s Growth.” IZA Discussion Paper 4764.

Broda, Christian, Joshua Greenfield, and David E. Weinstein. 2006. "From Groundnuts to Globalization: A Structural Estimate of Trade and Growth.” NBER Working Paper 12512.

Broda, Christian, and David E. Weinstein. 2006. "Globalization and the Gains from Variety.” Quarterly Journal of Economics, 121(2): 541-85.

Conference Board. 2010. “The Conference Board Total Economy Database: Output, Labor and Labor Productivity Country Details, 1950-2009” (Excel file). Accessed October 28, 2010. http://www.conference-board.org/subsites/fileretrieve.cfm?filename=1242\&id=2196.

Costantini , James A., and Marc J. Melitz. 2008. “The Dynamics of Firm-Level Adjustment to Trade Liberalization.” In The Organization of Firms in a Global Economy, ed. Elhanan Helpman, Dalia Marin, and Thierry Verdier, 107-41. Cambridge, MA: Harvard University Press. 
De Gregorio, José, and Jong-Wha Lee. 2004. "Growth and Adjustment in East Asia and Latin America.” Economía, 5(1): 69-134.

DeJong, David, and Marla Ripoll. 2006. “Tariffs and Growth: An Empirical Exploration of Contingent Relationships.” Review of Economics and Statistics, 88(4): 625-40.

Denison, Edward F. 1962. "The Sources of Economic Growth in the United States and the Alternatives before Us.” Supplementary Paper No. 13, New York: Committee for Economic Development.

Dollar, David, and Aart Kraay. 2004. “Trade, Growth, and Poverty.” Economic Journal, 114(493): F22-49.

Dornbusch, Rudiger, Stanley Fischer, and Paul A. Samuelson. 1977. "Comparative Advantage, Trade, and Payments in a Ricardian Model with a Continuum of Goods.” American Economic Review, 67(5): 823-39.

Dowrick, Steve, and Jane Golley. 2004. “Trade Openness and Growth: Who Benefits?” Oxford Review of Economic Policy, 20(1): 38-56.

Eaton, Jonathan, and Samuel S. Kortum. 2002. “Technology, Geography, and Trade.” Econometrica, 70(5): 1741-79.

Edwards, Sebastian. 1989. “Openness, Outward Orientation, Trade Liberalization and Economic Performance in Developing Countries.” NBER Working Paper 2908.

Edwards, Sebastian. 1998. “Openness, Productivity and Growth: What Do We Really Know?” Economic Journal, 108(447): 383-98.

Feenstra, Robert C. 1994. "New Product Varieties and the Measurement of International Prices.” American Economic Review, 84(1): 157-77.

Feenstra, Robert C., Benjamin R. Mandel, Marshall B. Reinsdorf, and Matthew J. Slaughter. 2009. "Effects of Terms of Trade Gains and Tariff Changes on the Measurement of U.S. Productivity Growth.” NBER Working Paper 15592.

Frankel, Jeffrey A., and David Romer. 1999. “Does Trade Cause Growth?” American Economic Review, 89(3): 379-99.

Gibson, Mark J. 2007. “Trade Liberalization, Reallocation, and Productivity.” Ph.D. thesis, University of Minnesota.

Guariglia, Alessandra, and Sandra Poncet. 2008. “Could Financial Distortions Be No Impediment to Growth After All? Evidence from China.” Journal of Comparative Economics, 36(4): 633-57.

Harrison, Ann. 1996. "Openness and Growth: A Time-Series, Cross-Country Analysis for Developing Countries.” Journal of Development Economics, 48(2): 419-44.

Holmes, Thomas J., and James A. Schmitz Jr. 2001. “A gain from Trade: From Unproductive to Productive Entrepreneurship.” Journal of Monetary Economics, 47(2): 417-46.

Hsieh, Chang-Tai, and Peter J. Klenow. 2009. "Misallocation and Manufacturing TFP in China and India.” Quarterly Journal of Economics, 124(4): 1403-48. 
Hu, Zuliu F., and Mohsin S. Khan. 1997. "Why Is China Growing So Fast?” Staff Papers International Monetary Fund, 44(1): 103-31.

Instituto Nacional de Estadística y Geografía. 2009. Estadisticas Historicas de Mexico 2009. Aguacalientes, Mexico: Instituto Nacional de Estadística y Geografía.

International Monetary Fund. International Financial Statistics Database. Accessed October 28, 2010. http://www.imf.org/external/data.htm.

Kambourov, Gueorgui. 2009. "Labour Market Regulations and the Sectoral Reallocation of Workers: The Case of Trade Reforms." Review of Economic Studies, 76(4): 1321-58.

Kehoe, Timothy J. 1992. "Modeling the Dynamic Impact of a NAFTA.” In A North American Free Trade Area, ed. William G. Watson, 24-34, Kingston: John Deutsch Institute.

Kehoe, Timothy J. 1994. "Towards a Dynamic General Equilibrium Model of North American Trade.” In Modeling Trade Policy: Applied General Equilibrium Assessments of North American Free Trade, ed. Joseph Francois and Clinton R. Shiells, 328-47, Cambridge: Cambridge University Press.

Kehoe, Timothy J. 1995. “A Review of Mexico’s Trade Policy from 1982 to 1994.” In The World Economy: Global Trade Policy 1995, ed. Sven W. Arndt and Chris R. Milner, 135-51. Oxford and Cambridge, Mass.: Blackwell.

Kehoe, Timothy J., and Edward C. Prescott. 2002. "Great Depressions of the 20th Century." Review of Economic Dynamics, 5(1): 1-18.

Kehoe, Timothy J., and Edward C. Prescott, eds. 2007. Great Depressions of the Twentieth Century. Minneapolis, MN: Federal Reserve Bank of Minneapolis.

Kehoe, Timothy J., and Kim J. Ruhl. 2008. "Are Shocks to the Terms of Trade Shocks to Productivity?” Review of Economic Dynamics, 11(4): 804-19.

Kehoe, Timothy J., and Kim J. Ruhl. 2009. "How Important Is the New Goods Margin in International Trade?” Federal Reserve Bank of Minneapolis Staff Report 324.

Kohli, Ulrich. 2004. "Real GDP, Real Domestic Income, and Terms of Trade Changes." Journal of International Economics, 62(1): 83-106.

Kose, M. Ayhan, Guy Meredith, and Christopher Towe. 2005. "How Has NAFTA Affected the Mexican Economy? Review and Evidence.” Monetary Policy and Macroeconomic Stabilization in Latin America, 2005: 35-81.

Krueger, Anne, and Aaron Tornell. 1999. "The Role of Bank Restructuring in Recovering from Crises: Mexico 1995-1998.” NBER Working Paper 7042.

Krugman, Paul. 1980. "Scale Economies, Product Differentiation, and the Pattern of Trade." American Economic Review, 70(5): 950-59.

Lee, Ha Yan, Luca A. Ricci, and Roberto Rigobon. 2004. “Once Again, Is Openness Good for Growth?” Journal of Development Economics, 75(2): 451-72.

Lewis, William W. 2004. The Power of Productivity: Wealth, Poverty, and the Threat to Global Stability. Chicago: University of Chicago Press. 
López-Córdova, Ernesto. "NAFTA and Manufacturing Productivity in Mexico.” Economía, 4(1): 55-98.

Lustig, Nora. 2001. "Life Is Not Easy: Mexico's Quest for Stability and Growth.” Journal of Economic Perspectives, 15(1): 85-106.

Maddison, Angus. 1995. Monitoring the World Economy: 1820-1992. Washington:

Organisation for Economic Co-operation and Development.

Maddison, Angus. 2010. "Historical Statistics of the World Economy: 1-2008 AD" (Excel file). Accessed October 28, 2010. http://www.ggdc.net/MADDISON/Historical_Statistics/horizontalfile_02-2010.xls.

McGrattan, Ellen R., and Edward C. Prescott. 2009. "Openness, Technology Capital, and Development.” Journal of Economic Theory, 144(6): 2454-76.

Melitz, Marc J. 2003. "The Impact of Trade on Intra-industry Reallocations and Aggregate Industry Productivity.” Econometrica, 71(6): 1695-725.

Milner, Chris, and Tony Westaway. 1993. "Country Size and the Medium-Term Growth Process: Some Cross-Country Evidence.” World Development, 21(2): 203-11.

Moreno-Brid, Juan Carlos, Jesus Santamaria, and Juan Carlos Rivas Valdivia. 2005. "Industrialization and Economic Growth in Mexico after NAFTA: The Road Travelled." Development and Change, 36(6): 1095-119.

Nye, Howard L. M., Sanjay Reddy, and Kevin Watkins. 2002. "Dollar and Kraay on 'Trade, Growth and Poverty': A Critique.” Columbia University.

Parente, Stephen L., and Edward C. Prescott. 1994. "Barriers to Technology Adoption and Development.” Journal of Political Economy, 102(2): 298-321.

Parente, Stephen L., and Edward C. Prescott. 2002. Barriers to Riches. Cambridge, MA: MIT Press.

Ramondo, Natalia, and Andrés Rodríguez-Clare. 2009. "Trade, Multinational Production, and the Gains from Openness.” http://www.econ.psu.edu/ aur10/Papers/TradeMPforJPE.pdf.

Rawski, Thomas G. 1994. "Chinese Industrial Reform: Accomplishments, Prospects, and Implications.” American Economic Review, 84(2): 271-75.

Rivera-Batiz, Luis A., and Paul M. Romer. 1991. "Economic Integration and Endogenous Growth.” Quarterly Journal of Economics, 106(2): 531-55.

Rodríguez, Francisco. 2007. “Openness and Growth: What Have We Learned?” Working Paper 51, United Nations, Department of Economics and Social Affairs.

Rodríguez, Francisco, and Dani Rodrik. 2000. "Trade Policy and Economic Growth: A Skeptic's Guide to the Cross-National Evidence.” NBER Macroeconomics Annual 2000, vol. 15, ed. Ben S. Bernanke and Kenneth Rogoff, 261-338. Cambridge, MA: MIT Press.

Rodrik, Dani, Arvind Subramanian, and Francesco Trebbi. 2004. "Institutions Rule: The Primacy of Institutions over Geography and Integration in Economic Development.” Journal of Economic Growth, 9(2): 131-65. 
Romer, Paul M. 1986. “Increasing Returns and Long-Run Growth.” Journal of Political Economy, 94(5): 1002-37.

Sachs, Jeffrey D., and Andrew M. Warner. 1995. "Economic Reform and the Process of Global Integration.” Brookings Papers on Economic Activity, 1995(1): 1-118.

Sala-i-Martin, Xavier. 1997. “I Just Ran Two Million Regressions.” American Economic Review, 87(2): 178-83.

Sato, Kazuo. 1976. “The Ideal Log-change Index Number.” Review of Economics and Statistics, 58(2): 223-28.

Schmitz, James A., Jr. 2005. "What Determines Productivity? Lessons from the Dramatic Recovery of the U.S. and Canadian Iron Ore Industries Following their Early 1980s Crisis.” Journal of Political Economy, 113(3): 582-625.

Solow, Robert M. 1957. “Technical Change and the Aggregate Production Function.” Review of Economics and Statistics, 39(3): 312-20.

Song, Zheng, Kjetil Storesletten, and Fabrizio Zilibotti. Forthcoming. “Growing Like China.” American Economic Review.

Spolaore, Enrico, and Romain Wacziarg. 2005. “Borders and Growth.” Journal of Economic Growth, 10(4): 331-86.

Tornell, Aaron, Frank Westermann, and Lorenza Martinez. 2003. "Liberalization, Growth, and Financial Crises: Lessons from Mexico and the Developing World.” Brookings Papers on Economic Activity, 2003(2): 1-88.

United Nations Conference on Trade and Development (UNCTAD). 2009. "World Investment Report 2009: Transnational Corporations, Agricultural Production and Development.” http://www.unctad.org.

U. S. Bureau of Economic Analysis. 2010. “Current-Dollar and 'Real' Gross Domestic Product” (Excel file). Accessed October 28, 2010. http://www.bea.gov/national/xls/gdplev.xls.

U.S. Census Bureau. "Statistical Abstract of the United States Database.” Accessed October 28, 2010. http://www.census.gov/compendia/statab/.

Vartia, Yrjö O. 1976. “Ideal Log-change Index Numbers.” Scandinavian Journal of Statistics, 3(3): 121-26.

Wacziarg, Romain, and Karen Horn Welch. 2008. “Trade Liberalization and Growth: New Evidence.” World Bank Economic Review, 22(2): 187-231.

Warner, Andrew. 2003. “Once More into the Breach: Economic Reform and Global Integration.” Center for Global Development Working Paper 34.

World Bank. 1987. World Development Report, 1987. New York: Oxford University Press.

World Bank. 2008. “Global Purchasing Power Parities and Real Expenditures.” In 2005 International Comparison Program. Washington, DC: World Bank.

World Bank. “World Development Indicators Database.” Accessed October 28, 2010. http://data.worldbank.org/. 
Yanikkaya, Halit. 2003. "Trade Openness and Economic Growth: A Cross-Country Empirical Investigation.” Journal of Development Economics, 72(1): 57-89. 


\section{Table 1}

Calculation of Broda-Greenfield-Weinstein (2006) welfare gains from variety

\begin{tabular}{lcc}
\hline & Mexico & China \\
& $1990-2000$ & $1998-2008$ \\
\hline Mean Elasticity & 6.704 & 5.634 \\
Median Elasticity & 3.070 & 3.488 \\
5th percentile lambda ratio & 0.832 & 0.789 \\
Median lambda ratio & 0.956 & 0.954 \\
95th percentile lambda ratio & 1.028 & 1.031 \\
Import price bias & 0.939 & 0.947 \\
Import log-change weight & 0.224 & 0.185 \\
Equivalent variation (percent) & 1.417 & 1.013 \\
\hline
\end{tabular}

Sources: Broda, Greenfield, and Weinstein (2006) and authors' calculations.

Table 2

Real GDP growth versus real income growth in Mexico and China

\begin{tabular}{ccccc}
\hline $\begin{array}{c}\text { Annual growth rate } \\
\text { (percent) }\end{array}$ & $\begin{array}{c}\text { Real GDP } \\
\text { per capita }\end{array}$ & $\begin{array}{c}\text { Terms of trade } \\
\text { premium }\end{array}$ & $\begin{array}{c}\text { Gain from } \\
\text { variety }\end{array}$ & $\begin{array}{c}\text { Real income } \\
\text { per capita }\end{array}$ \\
\hline China 1998-2008 & 8.989 & -0.761 & 0.101 & 8.329 \\
Mexico 1990-2000 & 1.782 & 0.169 & 0.142 & 2.093 \\
\hline
\end{tabular}

Sources: World Bank World Development Indicators and authors’ calculations. 
Figure 1

Trade in Mexico and China

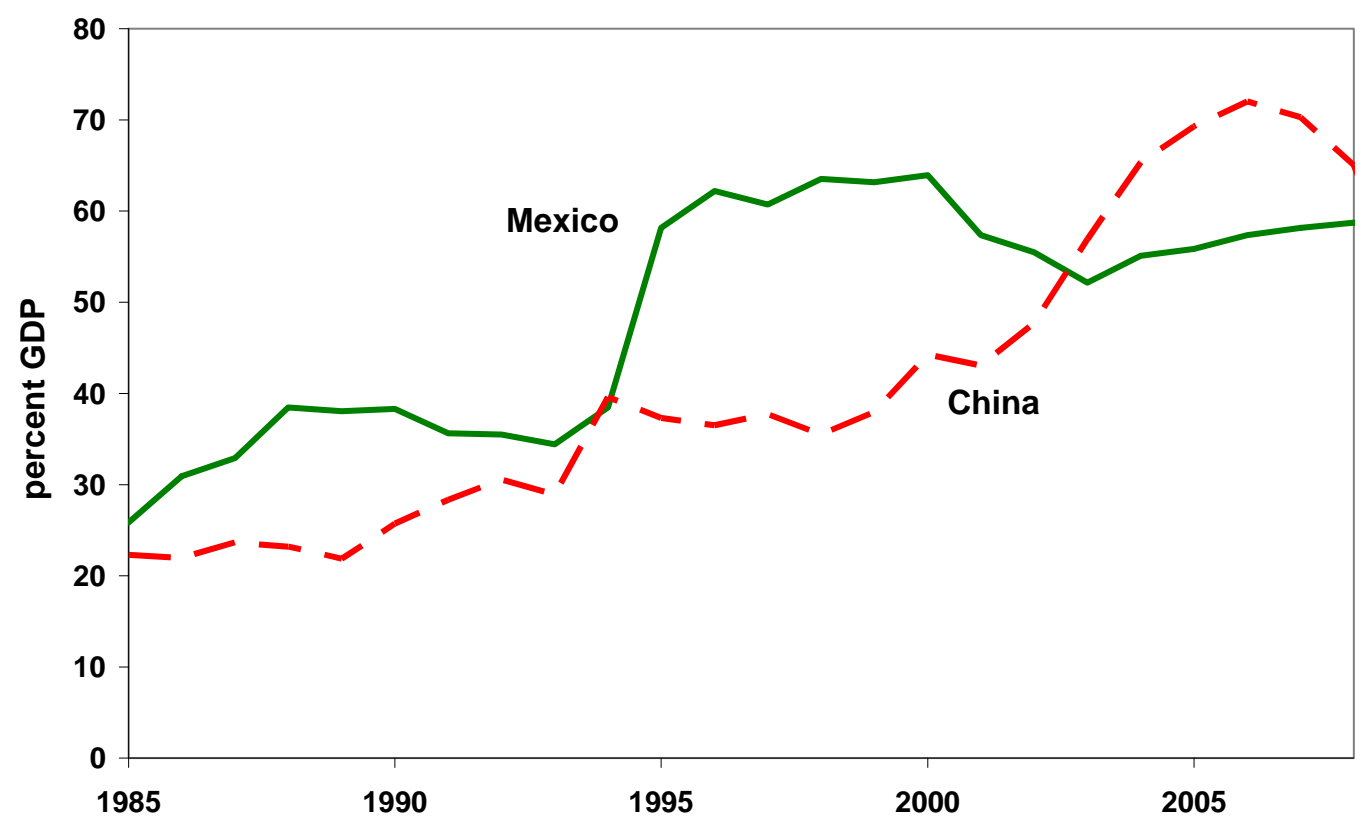

Source: IMF International Financial Statistics.

Figure 2

FDI inflows to Mexico and China

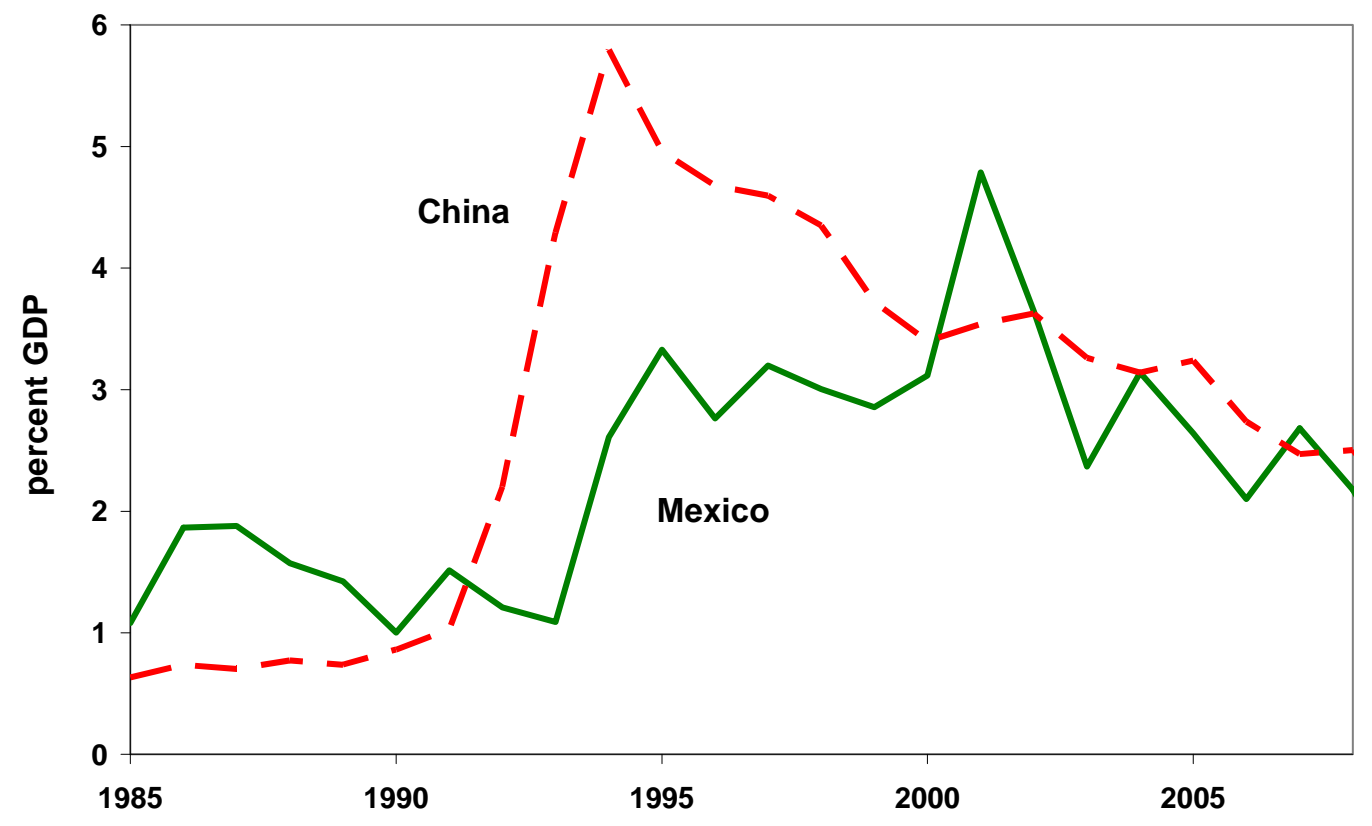

Sources: UNCTAD World Investment Report 2009 and IMF International Financial Statistics. 


\section{Figure 3}

\section{Real GDP per working-age person in Mexico and China}

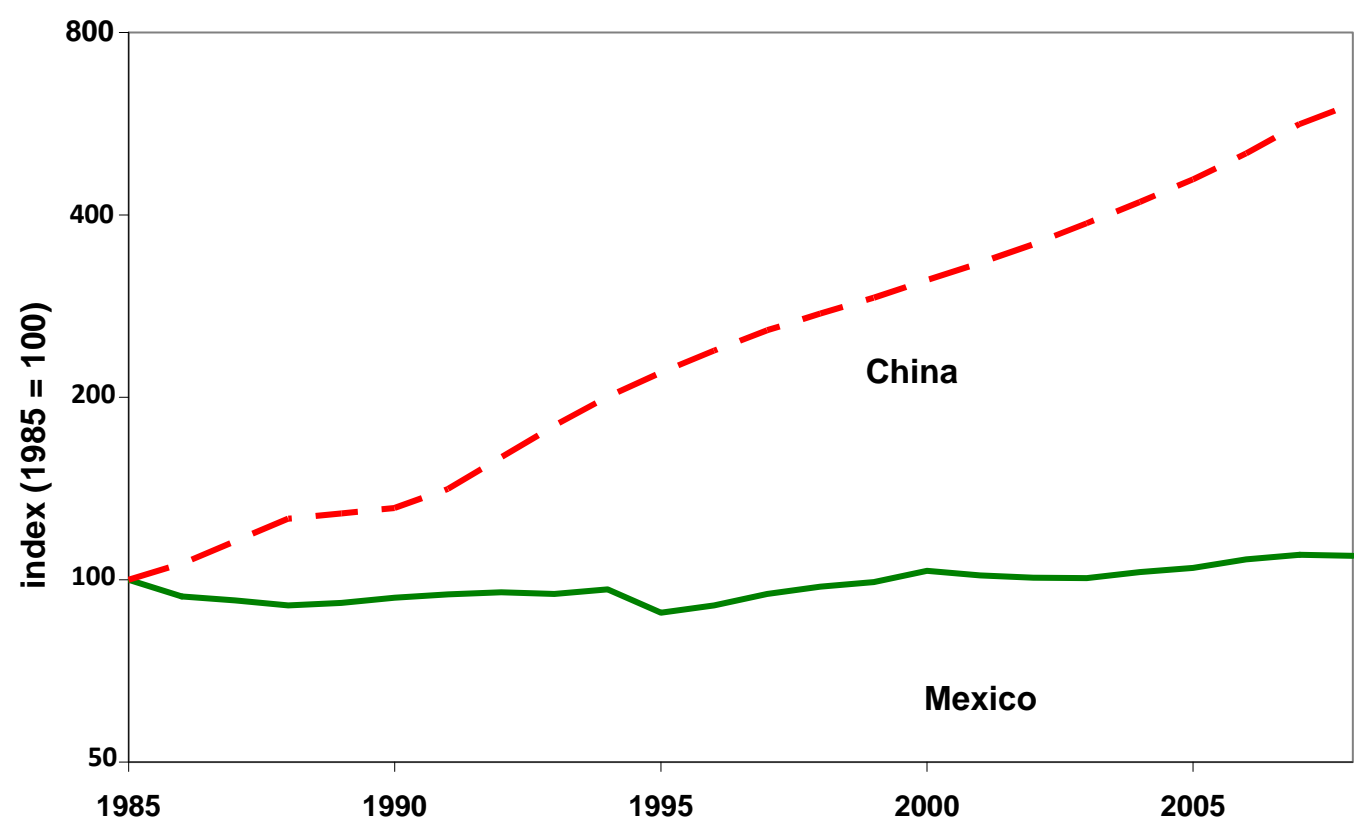

Sources: IMF International Financial Statistics and World Bank World Development Indicators.

Figure 4

\section{Terms of trade premium in Mexico and China}

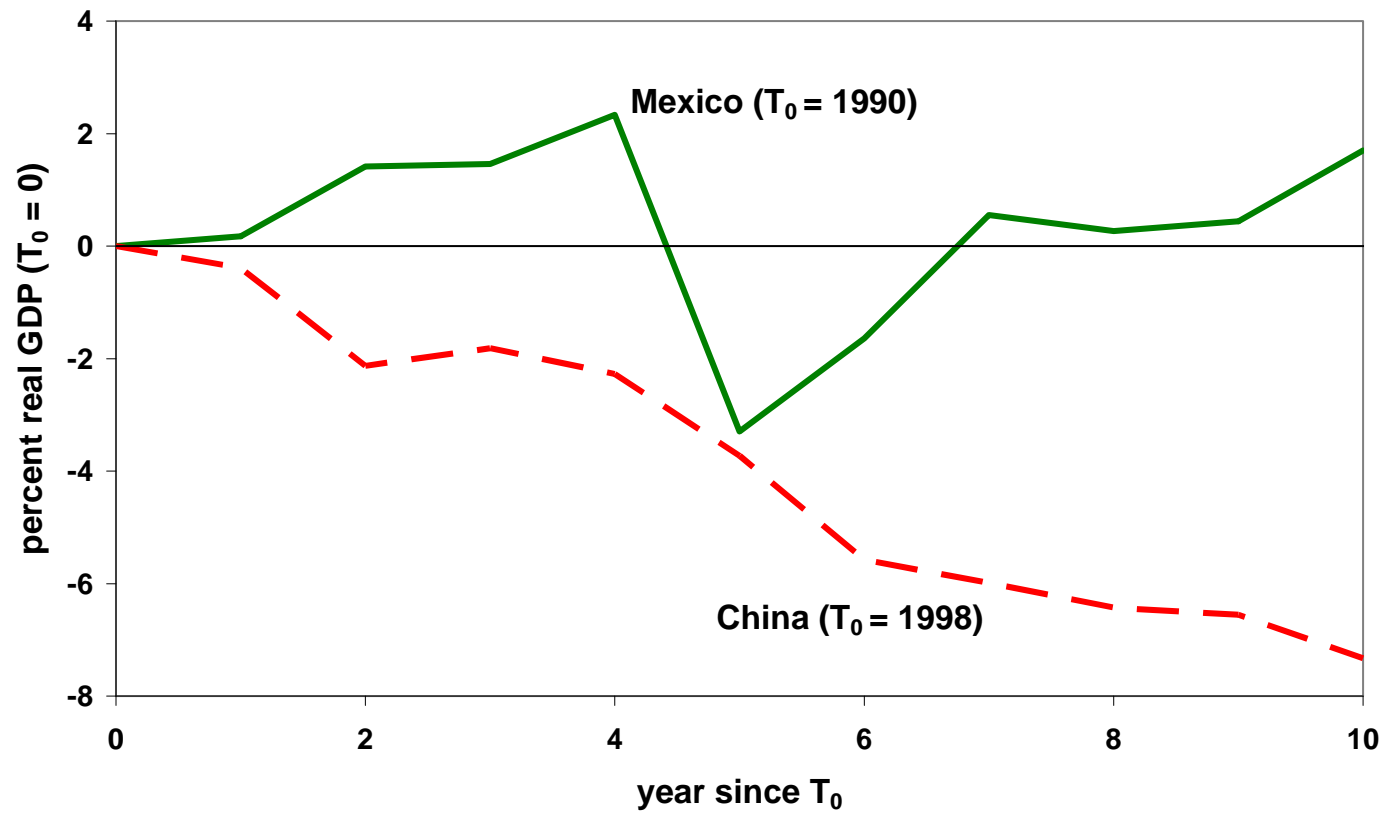

Sources: World Bank World Development Indicators and authors' calculations. 


\section{Figure 5}

\section{Growth accounting for China}

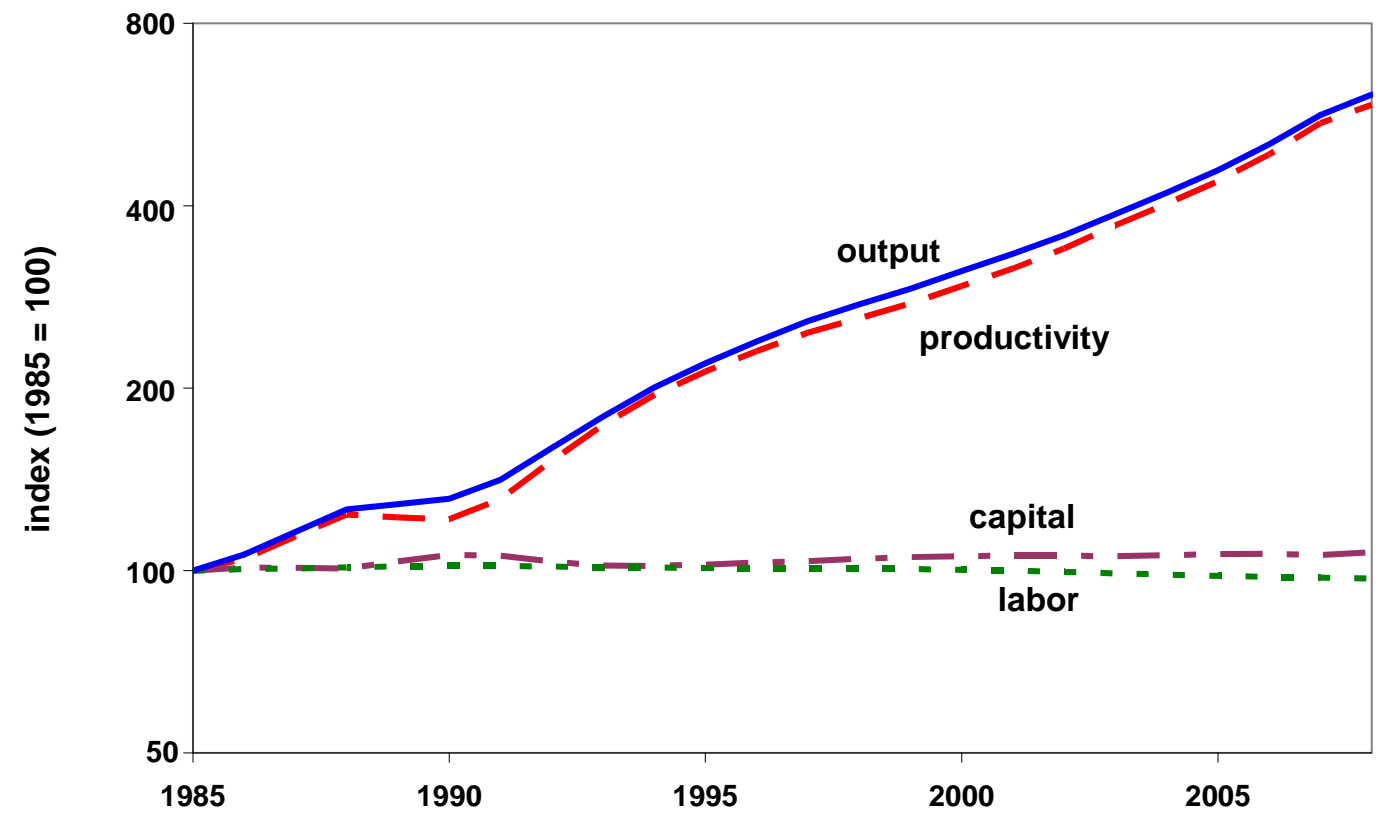

Sources: Conference Board Total Economy Database, IMF International Financial Statistics, World Bank World Development Indicators, and authors' calculations.

Figure 6

\section{Growth accounting for Mexico}

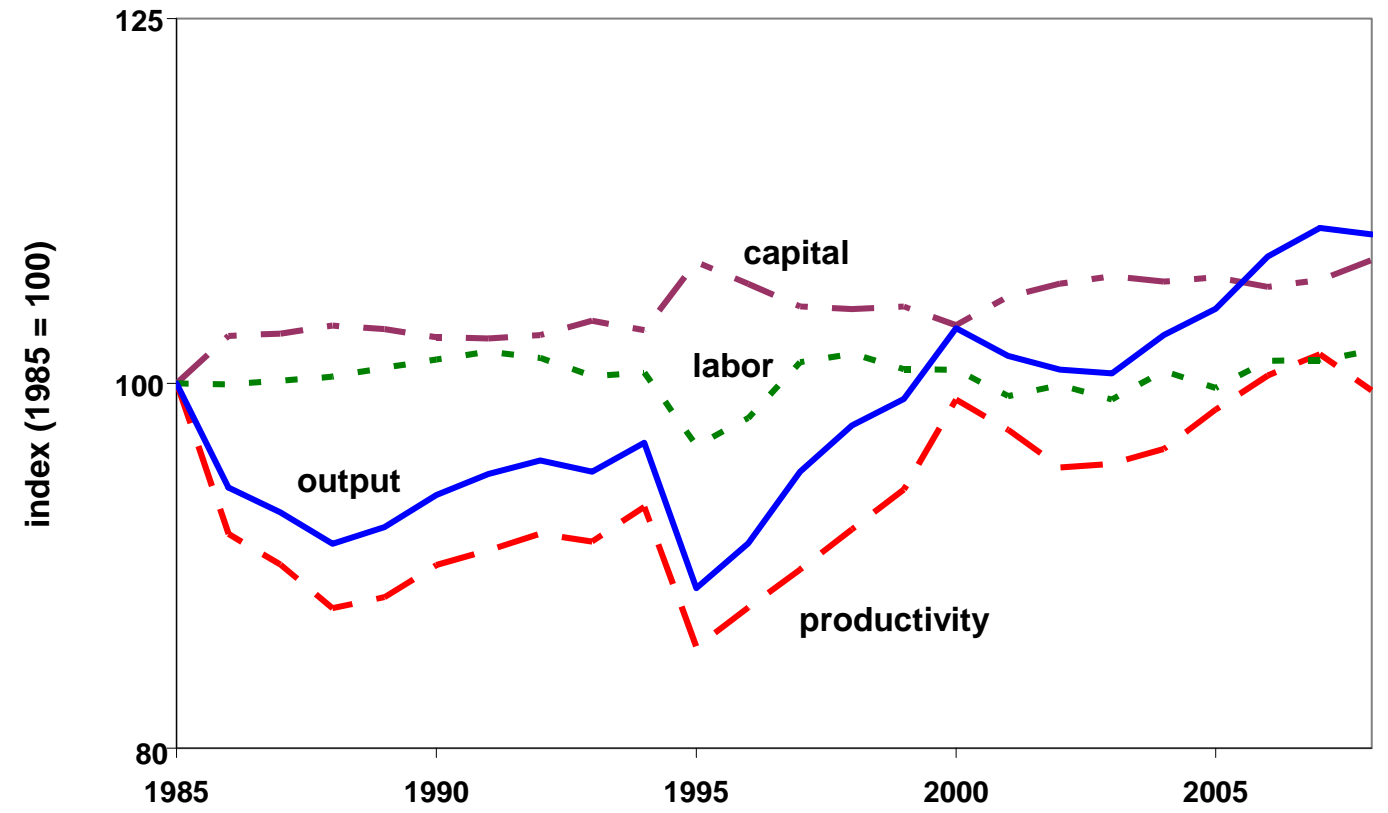

Sources: Conference Board Total Economy Database, IMF International Financial Statistics, World Bank World Development Indicators, and authors' calculations. 


\section{Figure 7}

Real GDP per working-age person in the United States

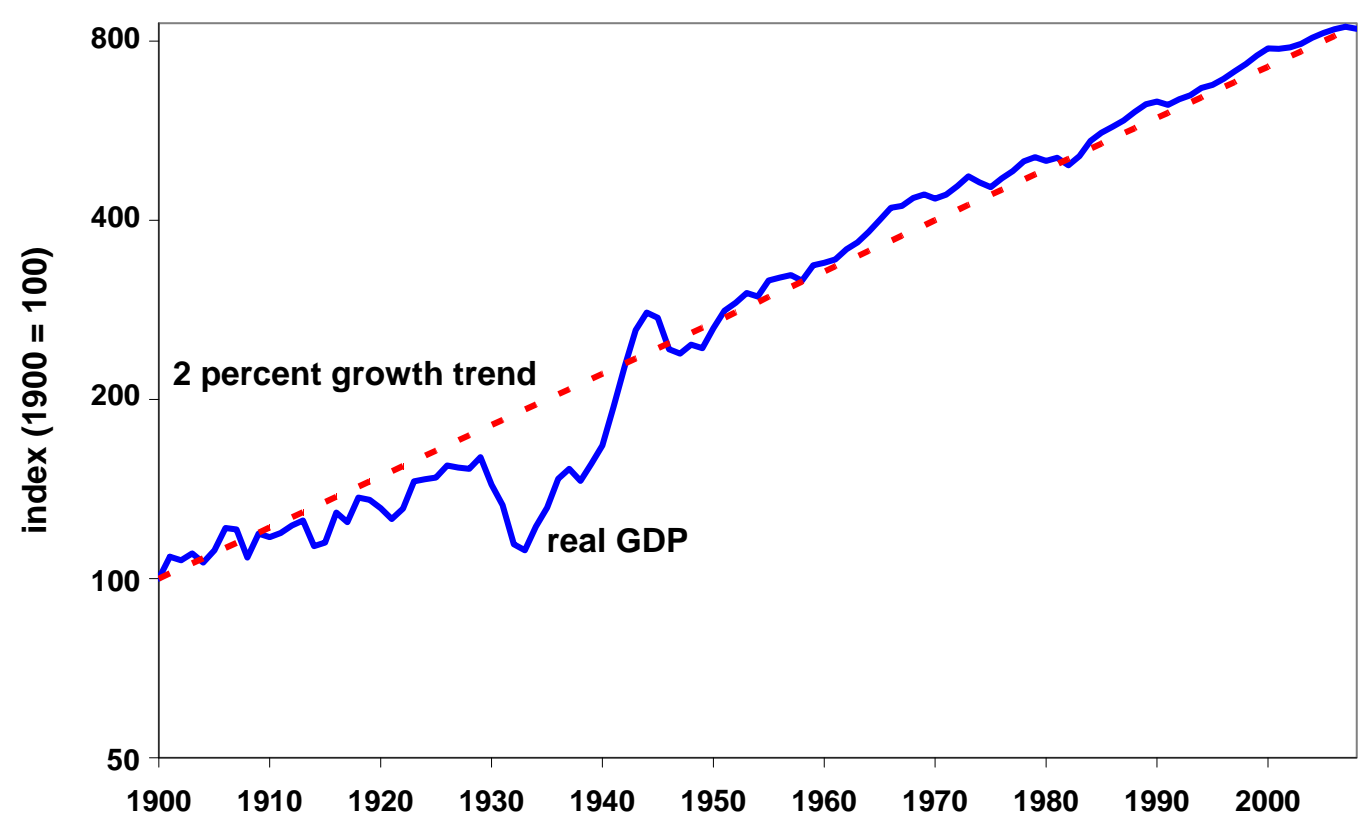

Sources: Maddison (2010), U.S. Bureau of the Census Statistical Abstract of the United States, and U.S.Bureau of Economic Analysis (2010).

\section{Figure 8}

\section{Real GDP per working-age person in Mexico}

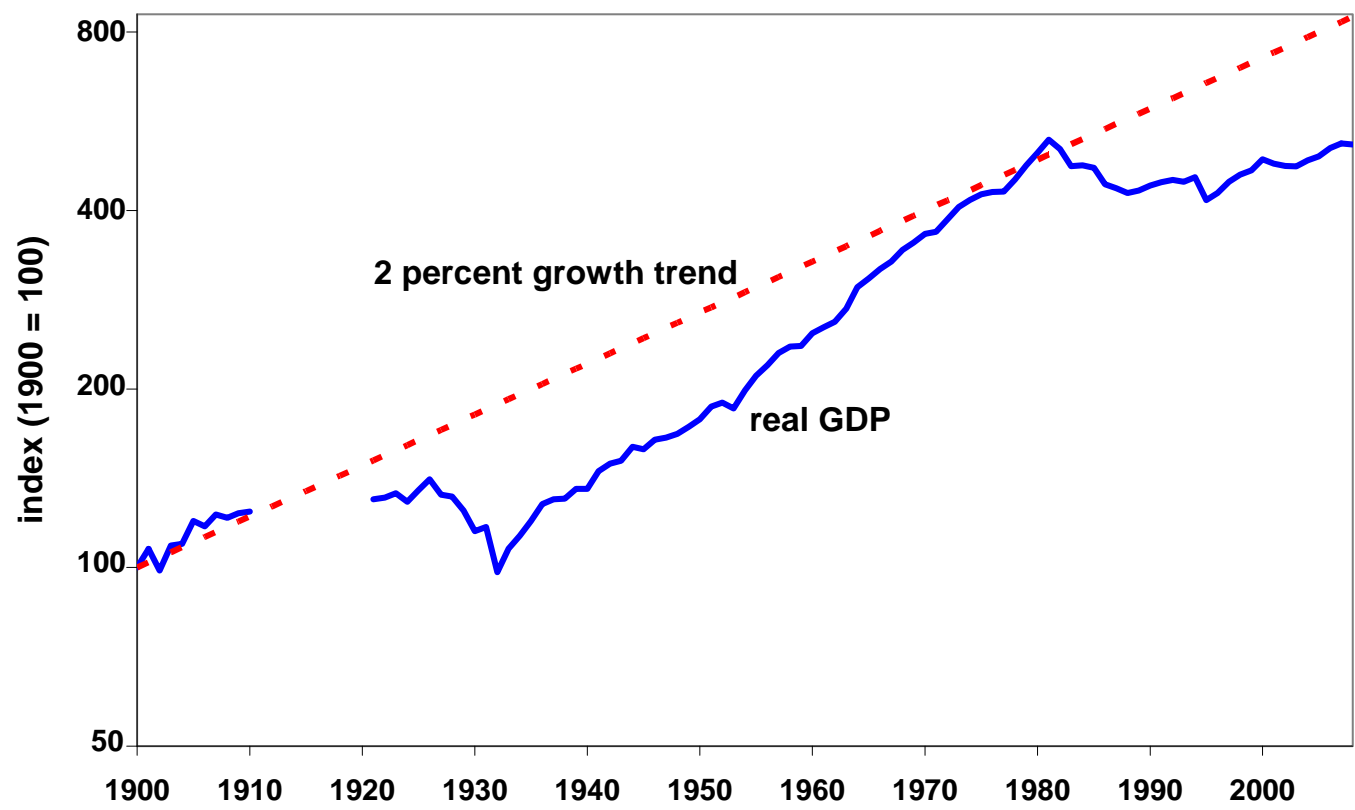

Sources: Maddison (2010), Instituto Nacional de Estadística y Geografía (2009), IMF International Financial Statistics, and World Bank World Development Indicators. 
Figure 9

Purchasing power parity GDP in Mexico and China

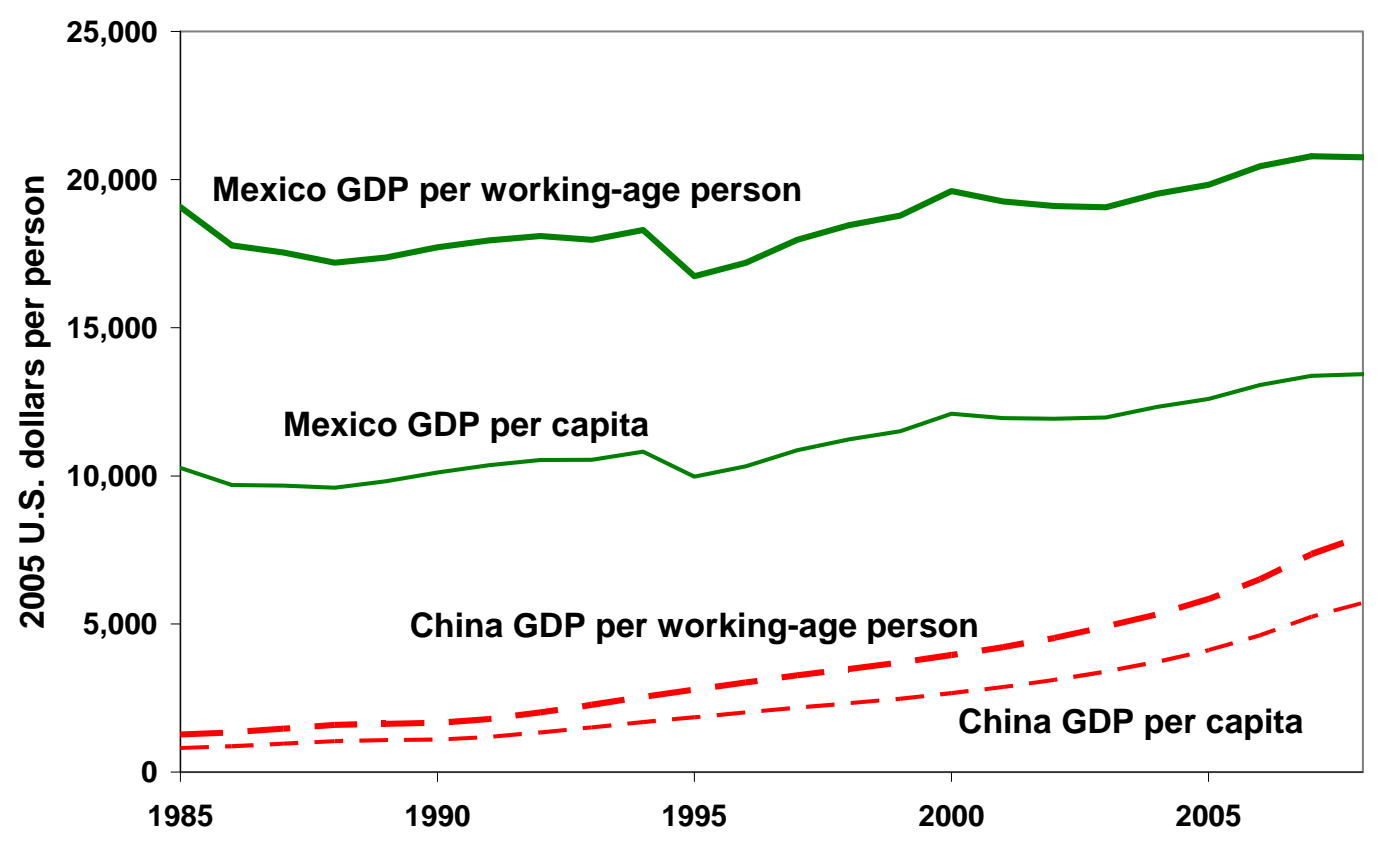

Source: World Bank World Development Indicators. 